\title{
Global Ecological Human Imprint, Sustainable Development and Environment: Assessment and Impacts
}

\author{
Safwat H. Shakir Hanna, Kendal T. Harris and Irvin W. Osborne-Lee ${ }^{1}$ \\ Gian Paolo Cesaretti, and Rosa Misso ${ }^{2}$ \\ Zacharoula S. Andreopoulou ${ }^{3}$
}

\begin{abstract}
Ecological Human Imprint $\left(\mathrm{E}_{\mathrm{HI}}\right)$, sustainability, and environment form three points of the triangle of technology development. These three points when integrated are the key to understanding how to improve global sustainability. The present research focuses on assessment and impacts of global issues of sustainability of human activities. This research uses modeling of these points and predicts the impacts of human activities on our global Earth and its natural resources and in consequence, the economic and social impacts. Further, the model uses assessments to develop suggestions about how to conserve our global environment and natural resources for future generations. The model is constructed on data collected and analyzed using published data from USA Agencies: United Nation Agencies and other public published data from different countries in the world. Stella ${ }^{\mathrm{TM}}$ software is used in the development of the model to make the prediction for the next 100 years.

The results of research applying the model are presented in three scenarios. These scenarios are formed applying (1) relaxed, (2) moderate, and (3) very conservative assumptions. In addition to these scenarios, predictions are developed according to the real-time data availability. According to the model, it is very important to maintain the trend of more efficient use of natural resources. Additionally, the more widespread education is very important to combat high demands for on natural resources and to conserve existing resources for continuation of global ecosystems and to supply life on Earth with the goods and services needed. Further, it is important to maintain the global the regenerative biological capacities (i.e. renewable resources) of Earth, while conserving (and developing new sources of) non-renewable resources. Finally, the model shows that the nations should close the gaps between population growth and the economic development.
\end{abstract}

Key Words: Ecology, natural resources, world population, sustainable development

\section{Introduction}

The Ecological Human Imprint $\left(\mathrm{E}_{\mathrm{HI}}\right)$ is a new index and isa new concept came from the idea of Ecological Footprint $\left(E_{F}\right)$ introduced by Rees (1992 a, b, 1998,2000,

| ${ }^{1}$ Texas Gulf Coast Environmental Data (TEXGED) Center, Chemical Engineering Department, Roy G. Perry, College of Engineering, Prairie View A\&M University, The Texas A\&M University, P.O. Box 235, Prairie View, TX 77446 -USA.

2Università degli Studi di Napoli "Parthenope", Dipartimento di Studi Economico Giuridici, Via G.Parisi - 13, Napoli, Italy.

3 Aristotle University of Thessaloniki, Faculty of Forestry and Natural Environment- Lab of Forest Informatics, P. O. Box 247, 54124, Thessaloniki, Greece. 
2003, 2006), Wackernagel (1994) and Wackernagel and Rees (1991, 1996 a,b). However, Ecological Footprint $\left(\mathrm{E}_{\mathrm{F}}\right)$, in spite of its merit and as a wonderful concept for calculating the human demand from the Earth, it is lacking the idea about the value of human as a precious an important element in the ecosystem. The human element in the ecosystem has provided an impact on the ecosystem in either negative or positive. This should be an important role of humans in the global ecosystem and global life of the planet Earth. In spite of the negative impacts of human element on the ecosystem, the ecological footprint did not consider the valuable aspect of human element on the ecosystem as a whole. Additionally, the calculation of global hectare and in spite of its validity in the global ecosystem, there is lacking the value of humans on it in the assessment. In this respect, the human element is not calculated in the global hectares. Only we calculated in a global hectare, is the demand of human from the Earth. However, philosophically, the human element as a component in the ecosystem should have part of the ecological footprint calculation, and this is not calculated.

Considerable attention must be taken in the human value added in the ecosystem as part of it. Philosophically, without the human element in the processes of the ecosystem cycles, there is and should no change in the ecosystem or the nature. Therefore, the ecosystem will be the same since the creation of the Earth. But because, the human being has not been added to the ecosystems, therefore, this addition must be included in the equation, positive or negative impacts. In this respect, the work of human being has not been evaluated as a value added. The only item is the product type that has been added in the ecological footprint. Further, the functionality of every component in the ecosystems should be accounted for in the ecological footprint. For example, soil fauna, microbial activities, large animals and other organisms should be included in the equation of the ecological footprint because they have functionality in the process of ecosystem bio-capacity addition on the Earth. Further, the biotechnological and technological advances of the human being must be considered in the assessment of $\mathrm{E}_{\mathrm{HI}}$ equation.

Sustainable development is based on three essential principles: 1) economic efficiency, in other words, seeking to maximize the benefits to the community by taking account of social and environmental costs, including externalized costs (total cost approach); 2) environmental care, that is to say the preservation of non-renewable natural resources, impact limitation and application of the precautionary principle; and 3) social fairness, i.e. solidarity with regard to the least privileged and contribution to reducing inequality.In contemporary "environmentally aware" society, sustainability has been a key goal of local and regional stakeholders, national governments, NGOs and transnational networks (Andreopoulou et.al., 2011). Especially in the context of the economic recession globally, new technologies have emerged with innovative goods and services challenging environmental sustainability and green growth, as a means to confront the economic crisis (Andreopoulou et.al., 2013).Inthe relationship of human impacts and sustainability on the global ecosystems, the sustainable development will not be separated from human imprints on the global environment. In this respect, sustainability is for the use of renewable natural resources in a way does not lead to its own destruction or degradation, or lead to a decrease in viability "renewable" for future generations (WHO, 2005, Lee, S.M., 1991). Further, it willbe maintaining a constant balance in an effective manner without decreasing or conflicting with the natural 
resources such as soil, groundwater and biomass. It is very important to focus on economic sustainable development (Rees, 2010) on the optimal management of natural resources, and by focusing on the getting the maximum benefits of economic development, without compromising the condition of services and quality of natural resources (MA, 2005, Shakir Hanna and Osborn-Lee, 2011, andAbson et.al., 2014).

In sustainability, the human focus of the definitions provided on sustainable development, where human development includes the lead to improve the level of health care, education and social welfare. There is recognition of this day of human development on the grounds, they are crucial for economic development and for installing early residents. In the words of the Human Development Report issued by the United Nations Development Program (UNDP), "The men, women and children should be the focus of attention - are spun about the development of people and not the people about development." and confirms definitions of sustainable development is increasingly that development should be participating, so that people participate democratically in making decisions that affect their lives, politically, economically, socially and environmentally. The human influences the sustainable development, where human development includes the lead to improve the level of health care, education and social welfare. There is recognition of this day of human development on the grounds they are crucial for economic development and for installing early residents. In the words of the Human Development Report issued by the United Nations Development Program, "the men, women and children should be the focus of attention - are spun about the development of people and not the people about development." And confirms definitions of sustainable development is increasingly that development should be participating, so that people participate democratically in making decisions that affect their lives, politically, economically, socially and environmentally. Additionally, the sustainable development must include the achievement of rapid transformation in the technological base of the industrial civilization, and there is a need for new technology to be cleaner and more efficient and better able to save natural resources, in order to reduce pollution, and help to stabilize the climate, and accommodate growth in population and in economic activity.

The important element that can be added to the definition of sustainable development is an element of fairness or justice. There are two types of equity are fairly human generations yet unborn, and that their interests are not taken into account when developing economic analyzes, and market forces do not take into account the interests of these savage. The second relates to redress those living today and those who do not have equal access to natural resources or the "good things" social and economic development. The world lives since the mid- seventies under the absolute domination of the world's financial capital, which displays stark disparity between the countries of the South and the North also devotes this disparity within the same states. Therefore, sustainable development must take into account these two issues.

The $\mathrm{E}_{\mathrm{HI}}$ is a tool to be used to evaluate the productive surface required by a population to satisfy its consumption of resources, its waste absorption needs and including the human technological factors. Therefore, the measurement of the pressure those humans put on nature, so that we can evaluate the influence we each have on the environment. It 
offers each of us the chance to assess our impact on the planet and to reduce our consumption of resources and our production of waste, and increase the technological efficiency of using the natural resources to reduce our footprint and act in favor of sustainable development. In this respect; WWF, in its 2010 report, Humankind uses the equivalent of a planet and a half to satisfy its needs. The Earth has exceeded its biocapacity by $50 \%$. To deal with the most urgent challenges, actions must be taken to reduce our environmental footprint and enable sustainable development. The following actions are recommended 1) increase the number of protected zones by $15 \%$ in environmentally-sensitiveareas; 2) participate in sustainable management of forests. According to the resolution of (Helsinki, 1993), these are the management and use of forests and wooded terrains, in such a way and intensity that they are able to maintain their biological diversity, their productivity, their regenerative capacity and their vitality. Such a management approach must preserve the ability to satisfy both now and in the future, the environmental, economic and social functions on a local, national and global level. The rational management of forests must not cause harm to other ecosystems; 3 ) stop excessive consumption of water and the segmentation of fresh water ecosystems; 4) eliminate over-fishing and destructive fishing practices (loss of edible fish, destruction of coral reefs, reduction of the diversity and richness of species); 5)invest in bio-capacity; 6) promote biodiversity and services rendered by ecosystems; 7) solve the problems of priorities between food and energy, generated by agro-fuels; 8) pay attention to the problems raised by allocating land and planning land use and 9) share limited natural resources.

The Present paper will discuss the term of "Ecological Human Imprint $\left(\mathrm{E}_{\mathrm{HI}}\right)$ " as a new terminology. The first author is defining the Ecological Human Imprint (EHI) by what the human impacts on the environment and natural resources from the impressions and dynamic effects and subsequent economic effects.Therefore, the $E_{H I}$ will add a new dimension to the ecosystem philosophy and the calculation of a new method of assessment of the global Earth accounting system and the ultimate goal of maintain the sustainability and economic growth.

\section{Philosophical Approach Of The Ecological Human Imprint $\left(\mathrm{E}_{\mathrm{hi}}\right)$}

Philosophical outlook on Ecological Human Imprint ( $\left.\mathrm{E}_{\mathrm{HI}}\right)$ for the existence of the human impacts on the environment and including economic dimensions, environmental dimensions and social dimensions. In consequence, the interactions between humans and the environment in which we are living and the subsequent effects of direct and indirect effects on humanity as a whole was felt globally including climate changes, lack of water, food and health problems and security problems.

Ecological Human Imprint is now considered one of the technological means of assessing human impacts on the environment in which they live. Ecological Humanity Imprint can estimate the amount of humanity needs from the natural resources and services provided by the environment and global Earth biological capacity and nonbiological resources. It is an important that we should warn of growing humanitarian needs of the natural resources, and non-renewable natural resources. The growing humanitarian groups' is meaning that the human population is increasing, which means 
the increased requirements of natural resources produced by the global environment. This philosophical outlook is very important because the question now is whether the environment in which we live is capable of supplying this huge amount of human population, the needs of natural resources, especially food, shelter, clothing and energy needed for the production process to meet the increasing demand for resources and needs permanent increase in the current time.

The important question is whether the terrestrial environment in which we live, where can be able to hold the permanent supply of growing the human needs that are not offsetby the truce delay in the use of resources to the degree to which the natural environment to be able to renew its biological capacity in order to continue to renew itself to handle the increasing of human population.

The Figure 1 and Figure 2 shows a realistic view of what is happening in the world in terms of population growth curve and increase natural resources, and this is in addition to the curved global growth in gross domestic product(GDP). From this graph, we can see that the increase of world population will reach into overdrive and is not balanced with the increase of the natural resources and with the development rate. This means that the curve of the population increase has exceeded the rate of development, and this represents a great danger for the development.

What are the solutions needed to meet the shortfall between the needs and sustainable development? The sustainable development must be at the level of population growth or even a little more that can encounter demand for natural resources and to ensure the covering of the growing needs of the population. The question that is needed to be answered is that the rate of the population increase will equal rate of the increase in natural resources or not?

\section{How Is the Process of Sustainable Development?}

The question is what must be taken into account; a valuable is the earth, and including the natural resources (i.e. the renewable and non-renewable) will suffice the growing needs of humans taking into consideration the basic needs. Is the ecological economy will be able to answer these questions? Do environmental economy can be able to answer questions of sustainable development? The environmental economy depends on the environmental feasibility studies to take advantage of the available natural resources. If the feasibility studies carried out it will be expensive, and then feasibility of their use is not important. The environmental economy depends on the exploitation of natural resources to get the useful national return. The environmental economy depends not only on yield but calculated into account that the production and use of natural resources you will benefit the largest number of people living on this earth.

The Global Environmental Economy in which is the population factor is very important in studies of international global environmental economy and international and that the philosophy of International is how to shift from market economy to environmental economics, which aims for sustainable development in the first place, which is designed to work the continuity of natural resources to the long-term in order to extend the humanity needs.

The philosophy approach in environmental economics is based on economy, the environment, continuity, sustainability of resources, and the use of natural resources to a 
large number of generations and for scheduled to use the resources for a large number of years. The environmental economy does not depend on an urgent and quick profit, but depends on the rotation of the resources of many natural cycles. So it can be the best use of natural resources for the benefit of the largest number of people. This type of economy depends on the preference optimization best use of resources and turns them into resources utilized to reduce waste and convert it into the economy incredibly basic and diversified economy.

Another aspect of economic development and environment is the political dimension.

The political dimensions of the economics of the environment and development must rely on policies of enough optimal use of resources, reduce waste, recycle natural resources, and exploitation optimization with interest the sufficiency of the largest number of people because without this awareness of the political and economic cannot any country with limited resources and increasing the number of residents increased significantly for the possibilities of natural resources to meet their needs. On the other hand, these countries cannot provide a decent living for all the people without encountering problems. Problem is likely to arise from inadequate community of basic needs; friction may arise between members of the community, and the clash arises and instability.

\section{Materials And Methods}

\section{1) Rethinking of the Calculation in the "Ecological Human Imprint $\left(\mathrm{E}_{\mathrm{HI}}\right)$ "}

In the ecological footprint (Rees,1992), (Wackernmagel, 1994) and Wackernagel and Rees (1991, 1996), they used and compared human demands on nature with the biosphere's ability to regenerate resources and provide services. It does this by assessing the biologically productive land and marine area required to produce the resources a population consumes and absorbs the corresponding waste, using prevailing technology. However, this system, did not calculate the value added of human element and other organismal elements in the ecosystem in the equation of regenerative capacity of the Earth or the demands from the Earth. This has not been philosophically calculated, because if we add these elements may we have different results. In the ecological footprint, we only calculated the demands and biological capacity of the Earth without regarding to all other elements in the ecosystems and globally.

Therefore, the Human Ecological Imprint ( $\mathrm{E}_{\mathrm{HI}}$ ) calculation methodology can be described as: 1) What is the value of human being on the ecosystems (i.e. this including positive and negative impacts); 2) What are the values of animals in the functionality of ecosystems; 3) What are the values of plants in the ecosystems' functionality; 4) What are the values the energy transformed of the processes of the ecosystems; 5) what are the values of water functionality in the ecosystems; and 6) what are the values of soil materials in the functionality of ecosystems.

In the theory of the Ecological Human Imprint $\left(\mathrm{E}_{\mathrm{HI}}\right)$, the thinking is to consider the above mentioned activities in the process of the ecosystems, and they are the results of major human activities plus the other components of Earth's environmental, including the biological and none biological components. In this sense, we are 
suggesting that to use the concept of information theory, which is considering all the elements of processes and converting it as elements of bits and bytes. In this respect, the conversion of all the elements to bits and bytes will add a new dimension to the ecological footprint and may be accurately assess the demands from the Earth and the assess the availability of resources. This will give a new approach in the accounting system of the Earth to calculate the production or the bio-capacity of the Earth and demands from the Earth. In my own believe, the assessment on the base of bits and bytes will produce better understanding of how are our ecosystems function through the activities of human beings and the other components of the ecosystems. Further; this will lead to avoid the challenges to the ecological footprint theory. These challenges include: 1) the lack of calculation of data consumption and data of production; 2) factors of yield which are sometimes are not available; 3) There is no calculations or information about the role of below the ground organisms' of the ecosystems and their functionality role in the formation of biological capacities; 4) There are no calculations or information about the role of the above ground animals or organisms functionality in the formation of biological capacities of the Earth; 5) The lack of the role of energy in the formation of biological capacity, in spite of the inclusion of the energy consumption in the ecological footprint demands from the earth. However, the inclusion of the energy footprint in the biological capacity is not calculated and in particular, the useful energy in the process; and 6) The lack of the value added of human activities positively or negatively on the regenerative capacity of the Erath.

Accordingly the present method of $\left(\mathrm{E}_{\mathrm{HI}}\right)$ is a new endeavor for assessing the human demands and the production of bio-capacities from our planet Earth. This method of the new assessment is depending on the informatics based theory (Shannon and Weaver 1949). In this theory, the consideration is given for the bits and bytes of a system which are finite elements and are limited, in the universe. Therefore; because of the number of the elements $(S)$ in the universe or the Earth can be numbered into 1 to $\mathrm{N}$ and the need to evaluate the probability of the existence of their functionality in the earth, the probability in doing a function is equal $\operatorname{Pr}(\mathrm{S}=\mathrm{i})=$ pi; this means that we are making a pick of out any given functionality in the ecosystems at the most is, the $\log \mathrm{N}$, taking the logarithm to base two. The following formula can be applied as: $-\sum$ pi $\log _{\mathrm{e}}$ pi. This will allow to asses functionality in the ecosystem to produce the right quantitative analysis of the bio-capacities and the demands from the global Earth.

\section{2) Application of the Theory and Formulas of the Model}

The application of the theory will be collecting the information about the probability of each function of every component on this global Earth that has a role in the production of bio-capacities and the demands from the Earth. The following are the components of the participations in the production for goods and services from the Earth natural resources. In this respect, cropping lands is providing about 25-28\%, grazing lands is providing $10-11 \%$, forest lands is providing $33-38 \%$, fishing ground is providing $7-8 \%$, built-up lands $3 \%$, and the technological factor is providing about of 23 - $30 \%$ of human beings role and is representing the activities' on this Earth (i.e. in agriculture, in industry, in service sector, and other activities in the global universe). On the other hand, the demands from the earth; cropping lands is providing about $31 \%$, 
grazing lands is providing $11 \%$, forest lands is providing $12 \%$, fishing ground is providing $4 \%$, carbon demands from energy $30 \%$, built up lands $3 \%$ and the technological factor is providing about of $9 \%$ of human beings role and is representing the activities demands from this Earth. The materials involved are 1) cropped lands; 2) grazing lands; 3) forest lands; 4) fishing ground; 5) built-up land and 6) human resources that are producing the forces of production and technological advances. In this respect, the data of human population and other resources were gathered from published series from different agencies such as World Bank, UN Food and Agriculture Organization (FAO 1960-2008 FOASTAT and 2008 FOASTAT), NOAA (2012), United States Department of Agriculture (USDA, 2012), United Nation Development Program (UNDP), United Nation Environmental Program (UNEP, 2009), (UNFPA, 2001), WWF reports, 2002, 2004, 2006, 2008, 2010, and 2012, (WHO,2005), WRI 190-2005 series, WRI 2000, and 2012 and World Bank Data (1960-2012 series ). The data were analyzed using the regression, correlation, and statistical methodologies using Sigma Plot Software (Version 8, Version 11.2), 2D software of SPSSSCIENCE, 2002, (2009-2010), STELLA software (2001), and SAS, 2010.

Accordingly, the information from the published series, were tabulated and, used to assess the biological capacities of the Earth and the demands from the Earth using information theory technique. Green Informatics constitute a new term in the science of information that describes the utilization of informatics in the interest of the natural environment and the natural resources regarding sustainability and sustainable development (Andreopoulou, 2012).This added another dimension to the ecological footprint and converted to Ecological Human Imprint ( $\mathrm{E}_{\mathrm{HI}}$ ) which produced the correct assessment of the needed materials' supplies and the consumptions. Formulas were constructed to be used in the model for assessing the $\mathrm{E}_{\mathrm{HI}}$. These formulas are:

1) Relationship between Global Human Growth rate (GHGR) rate and Global Domestic Growth Rate (GDPR) in different years as: $\mathrm{Y}=-151.62+0.08$ Xand $\mathrm{Y}=582884.98-877.04 \mathrm{X}$ $+0.44 \mathrm{X}^{2}-0.00007 \mathrm{X}^{3}$.

2) Relationship between Global Biological Demands (GBD) / per capita and Global Biological Capacity $(\mathrm{GBC}) /$ per capita and number of years as $\mathrm{Y}=-31.36+466.08 \mathrm{X}-0.23 \mathrm{X}^{2}+$ $0.000004 \mathrm{X}^{3}$ and $\mathrm{Y}=84.88-0.041 \mathrm{X}^{2}$.

3) Relationship between $E_{H I}$ index calculated by information theory, including the human technological advances and $\mathrm{E}_{\mathrm{HI}}$ biological demands and $\mathrm{E}_{\mathrm{HI}}$ biological capacity indifferent years as $\mathrm{Y}=-217.11+0.11 \mathrm{X}$ and $\mathrm{Y}=-223.14+0.12 \mathrm{X}$.

4) Relationship between Global Human Population (GHP) and Ecological Footprint (Demand from the Earth) in global hectare $\mathrm{Y}=-0.28+2.56 *$ (GHP).

5) Relationship between Global Human Population (GHP) and Ecological Bio-capacity Footprint (Bio-capacity of the Earth) in global hectare $\mathrm{Y}=4.65-0.45^{*}(\mathrm{GHP})$.

6) Relationship between human population and maintenance index of Earth in supporting all humans on the Earth using advanced technologies and using information theory $\mathrm{Y}=2.29$ $0.23 *$ (GHP).

\section{Results}

\section{1) Ecological Human Imprint Analysis}

According to recent United Nations estimates, global population is increasing by approximately 80 million — the size of Germany — each year (Vital Sign, 2012, UNDP, 
2013). Although fertility rates have declined in most areas of the world, population growth continues to be fueled by high levels of fertility, particularly in Asia and Africa. Continued high fertility in many developing regions, coupled with low fertility in more-developed regions, means that 80 percent of the global population now lives in less-developed nations. The most-recent World Watch Institute edition of its Vital Signs surveys (2012) some of the most significant global trends affecting the environment are 1) global energy intensity increases and the rise in global oil consumption; 2) the fall of fossil-fuel consumption subsidies; 3) the rapid ascent of global wind power capacity and solar photovoltaic generating capacity; 4) the peak production of passenger cars and light trucks; 5) the increase in global biofuel production; 6) the prevalence of organic farming methods, per / capita meat consumption in the developing world; 7) the extraordinary growth in fish farming (50-fold since the 1950s, now accounting for 40 percent of total fish catch), and 8) the rise in the number of overweight people age 15 or older worldwide (up to 25 percent since 2002, to 1.93 billion people). Further, (UNDP, 2013) indicated that the growth in global emissions of carbon dioxide (CO2) is accelerating, and emissions today are more than 46 per cent higher than their 1990 level. Forests continue to be lost at an alarming rate. Overexploitation of marine fish stock is resulting in diminished yields. More of the earth's land and marine areas are under protection, but birds, mammals and other species are heading for extinction at an ever faster rate, with declines in both populations and distribution.

Tables $(1 \& 2 \& 3)$ and Figures (1) indicate that the $\mathrm{E}_{\mathrm{HI}}$ as an index is including in it, the human advanced technologies in the calculation. In this respect, the diagram explains that the ecological human imprint of threats, impacts and positive and negatives value added of increasing human population. These impacts include the advanced technologies which have positive and negatives properties in order to satisfy the human needs from goods and services that are required natural resources to support all the human activities. Furthermore, $\mathrm{E}_{\mathrm{HI}}$ appraises the total bio-productive area needed to sustain a defined society's activities, wherever these areas are located on Earth. The $\mathrm{E}_{\mathrm{HI}}$ accounts for three functions of ecosystems used by humans-resource supply, waste absorption, and space occupied for human infrastructure, in addition to the advanced technologies of human power of additions of technologies' which improve the use of the natural resources to increase the efficiencies of use of natural resources. In addition to the advanced technologies, the negative impacts of increasing human of using these natural resources and loss of habitats and increasing poverty and impacts on social and behavioral activities. Further, in general, the Footprint underestimates the impact of human activities on the biosphere. In addition, ecological footprint focuses on renewable resources while the footprint provides limited information about most non-renewable resources and their impact on ecosystems except the fossil fuel. This that what is the $\mathrm{E}_{\mathrm{HI}}$ is trying to add and include the human advances' technologies for both the biological capacities of Earth (i.e. technological advances in production; creation of biological capacities and reduction and recycling of wastes make high efficiency of use of the natural resources) and the biological demands from the Earth which can be translated to the waste produced, which added to the demands from the Earth (i.e. technological advance for production of waste and most harmful materials). 
Ecological Human Imprint $\left(\mathrm{E}_{\mathrm{HI}}\right)$

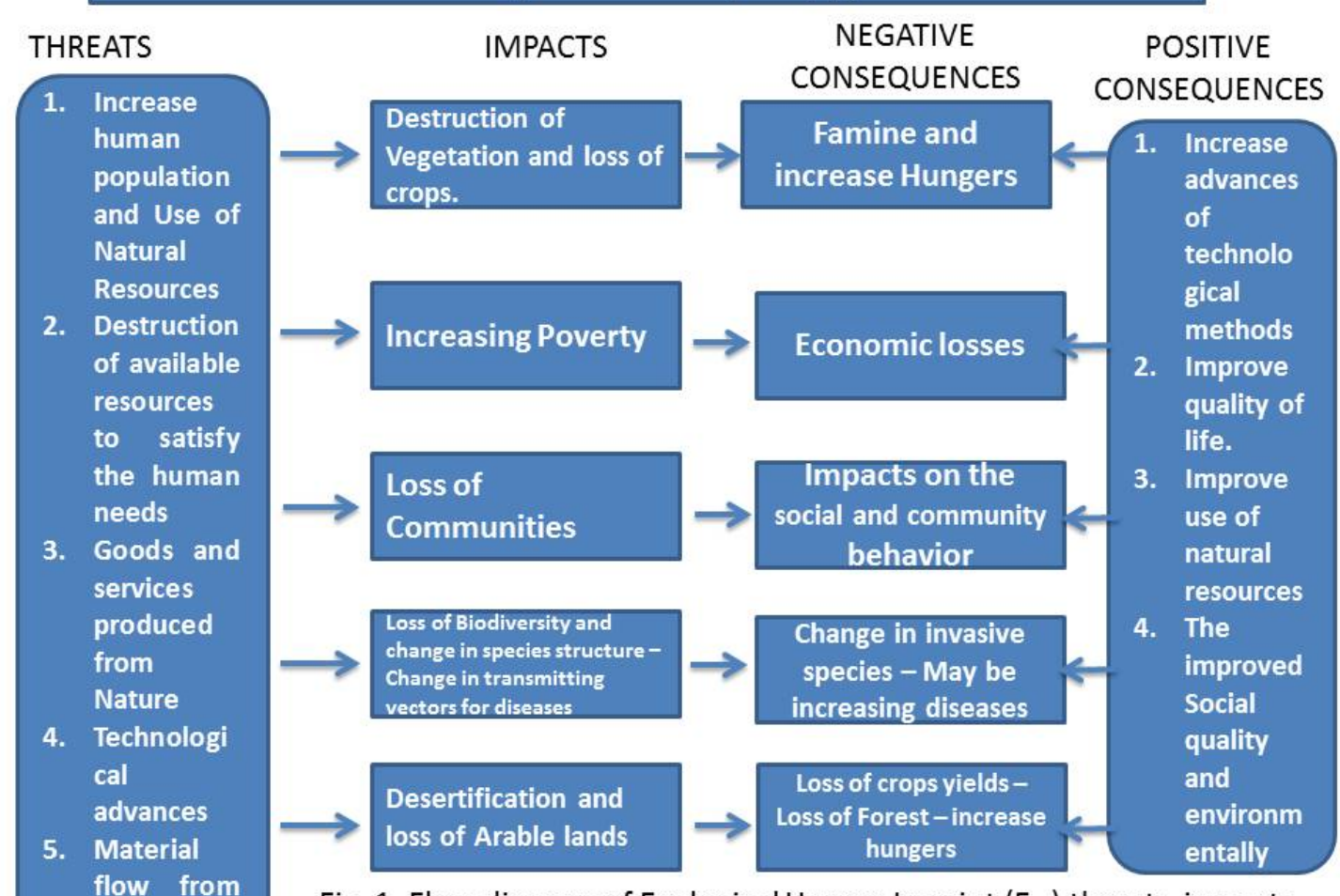

Fig. 1. Flow diagram of Ecological Human Imprint $\left(E_{H I}\right)$ threats, impacts, and positive - negative value added of increasing human population

\section{2) Relationship Between Human Population, Global Domestic Product, Technological Advances and Sustainability}

Figure 2 indicates the relationship between human population growth and global growth rate of Global Domestic Product (GDP) in \%. From the graph, it is noted that there is a gap between the human population growth and the growth rate of GDP. This gap indicates that if growth of human population is increasing than the global growth rate of GDP, there will be a shortage of the existing resources that allow production of goods and services that are needed for consumption of all human beings including the technological advances, that most of the economists depending on it to meet the demands from global Earth resources. From the above point of view, we need to express the concern; of the higher demands than the availability of supplies of goods and services that are available even we have advances in technological aspects. One of the hypotheses is that if we have the technologies that can reach a $100 \%$ of technological factor, there will be a gap between the human population growth rather than the growth of GDP. This is the concern. In addition to that, the stresses that can be accompanied to the advance of the technological factors, that will produce lot of pollutions, environmental problems, health problems and additional stresses such as the human 
social impacts and economic stresses. These impacts can be harmful and can lead to reduction of human quality of life. Is this the issue that we want to reach in this regard? Further, even the technological advances for example in genetic engineering of the crops or agricultural products and for the sake of hypothesis that if we have made advances in production of crops to reach 100\% improving in doubling the yield of crops and agricultural crops, then the question is this advancement will produce the goods and services to meet the growing demands of human population from food and other products? Further, we need to think for the coming the new generations. In theoretical, we cannot make advances to make the yield of crops to be $100 \%$ more than the existing yield of any crop. The reason, if the advances in genetic of the seeds to be planted, the seeds may need extra water resources and better soil condition and good climatic status. However, we have seen global climatic changes such as global warming and drought that can affect the life cycles of biological materials that can produce the food and biological capacities of the Earth.

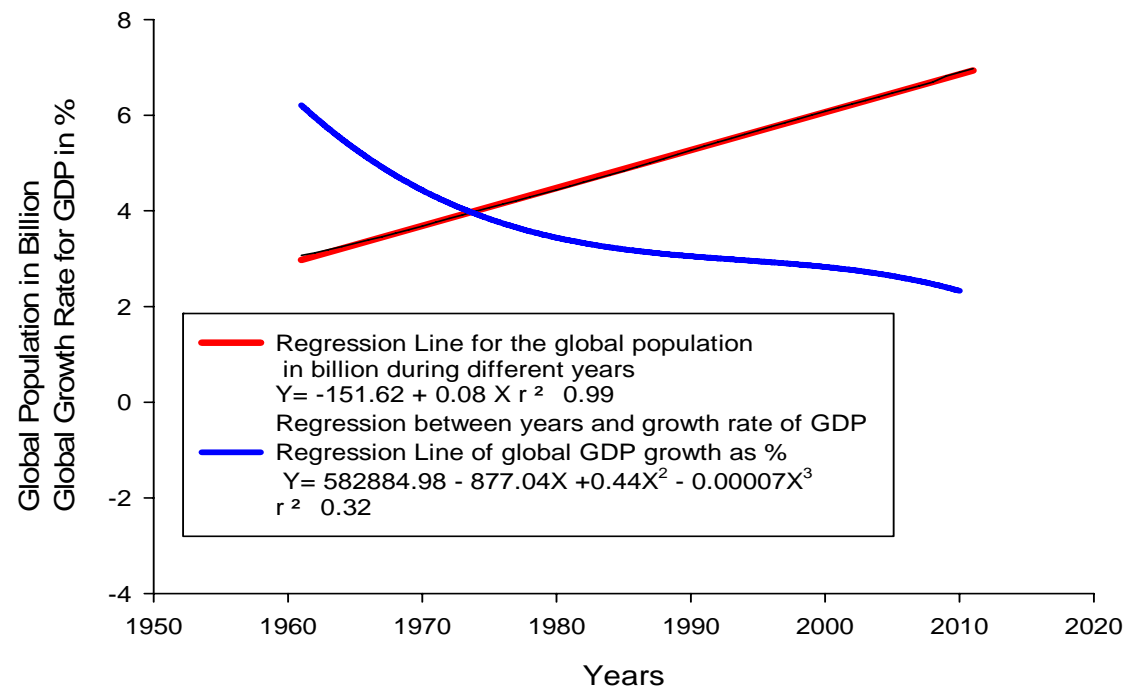

Figure (2) Relationship between global population growth and growth rate of global GDP 


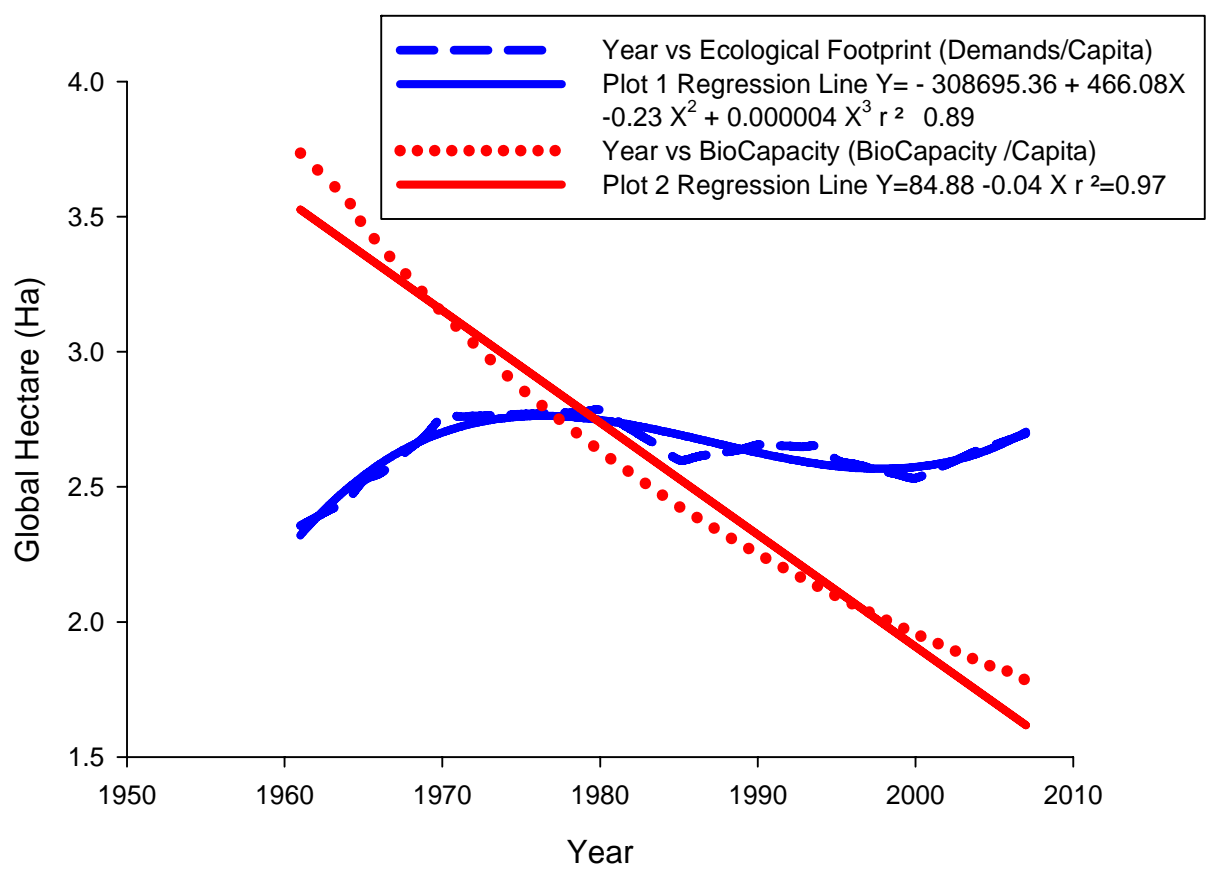

Fig. (3) The relationship between global biological demand / capita and global biological capacitiy / capita in global hectare during years 1950-2010 in global hectare

In order to discover the importance of global biological capacity of the Earth from the ecological footprint bio-capacity data and the ecological footprint data demands from the Earth for goods and services, we can discover that the biological capacity of the Earth is in decline against the demands from the Earth as shown in Figure 3. This will indicate that the global Earth will not be able to support the human population. In consequence, the issue of sustainable development will be in question. Further; sustainable, economic growth must be much less material and energy intensive than at present (Pearce, 1994). Therefore the supports of the case for ecological tax reform in aid of resource conservation (von Weizsacker, 1994). For example, depletion taxes and marketable quotas on natural capital inputs to the economy would: a) stimulate the search for more materially and energy-efficient technologies; b) preempt any resultant cost savings, thereby preventing the economic benefits of efficiency gains from being redirected to additional or alternative forms of consumption, and; c) generate an investment fund that could be used to rehabilitate important forms of self-producing natural capital (Rees, 1994, Rees, 2008, Rees, 2006, Rees, 2013 and Shakir Hanna et.al., 2011, 2013a).

\section{3) Using Ecological Human Imprint Method as Described Above}

Ecological human imprint $\left(\mathrm{E}_{\mathrm{HI}}\right)$ indicates that the bio-capacity and demand from the environment can be used in closing the gaps between the biological capacity and 
demands from the Earth. In this respect, the functionality of the $\left(\mathrm{E}_{\mathrm{HI}}\right)$ can help in increasing the biological capacity of Earth through the technological advances and the best efficient consumption of the natural resources. This will lead to extend the time of using of the natural resources and the biological capacity of the Earth. Using the information theory of bits and bytes will allow the closing the gaps in the data, and it is taking into account the technological advances of human beings. In other words, it brings the gaps between consumption and production and renewability of natural resources to year 1992 rather than the year 1981. Figures (4 and 5) show that there is no gap between the total $\mathrm{E}_{\mathrm{HI}}$ demand from the Earth and the total $\mathrm{E}_{\mathrm{HI}}$ production from the Earth. However, there is still a big deficit in production rather than the consumption in the year after 1992. Therefore, when we included the technology factor of the human being in $\mathrm{E}_{\mathrm{HI}}$, it shows the closing gap between the demand and production, including the renewability of the natural resources for the sake of production of goods and services. This gave the Earth about 11 years to reach the breakeven point between demands and production.

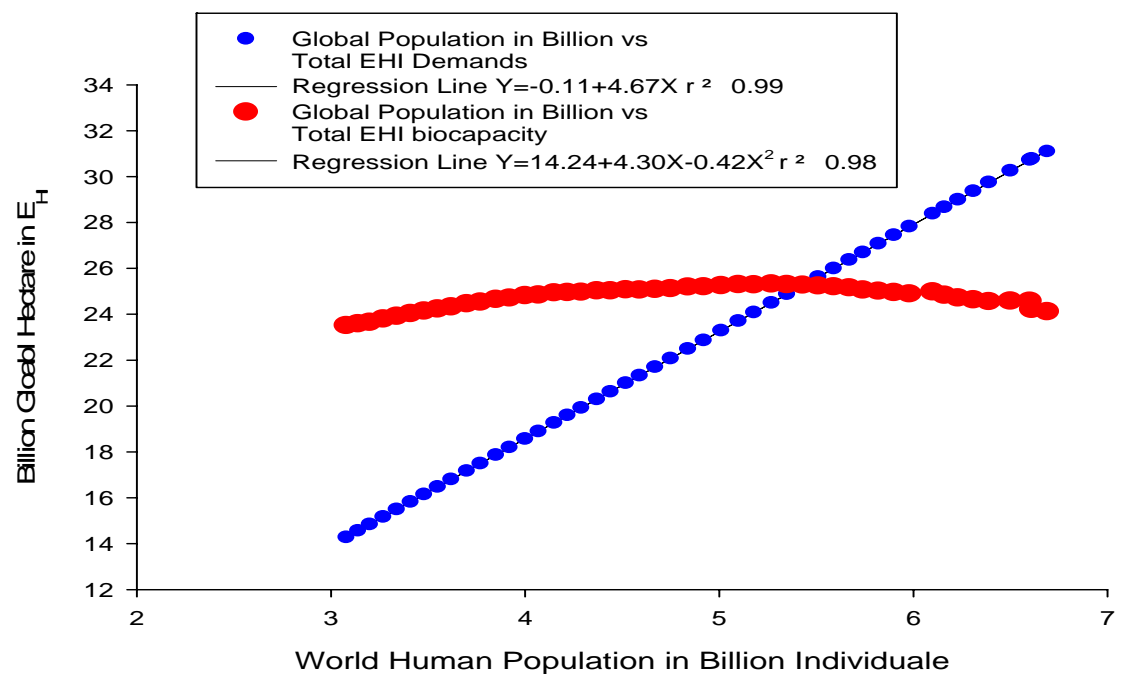

Fig. (4 ) Relationship between world human population and $E_{\mathrm{HI}}$ demanc and $E_{\mathrm{HI}}$ biocapcity from the Earth using the information theory includina the human technoloaical factor 


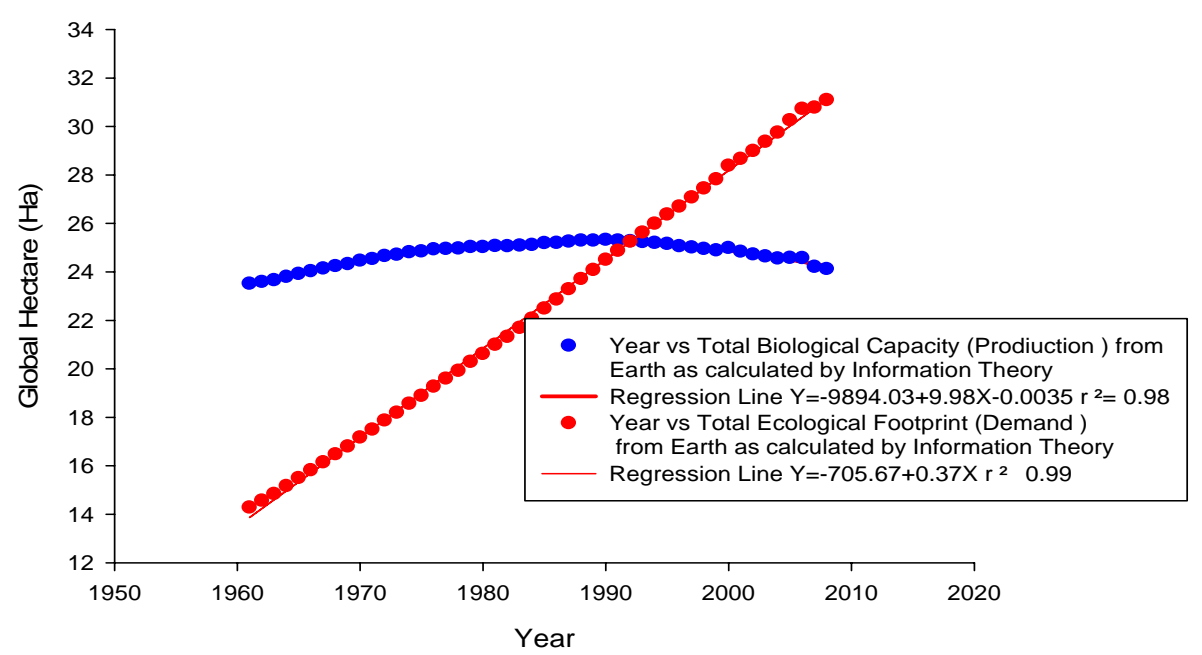

Fig. (5) Relationship between years and $E_{\mathrm{HI}}$ biocapacity from the Earth using the information theory including the human technological factor

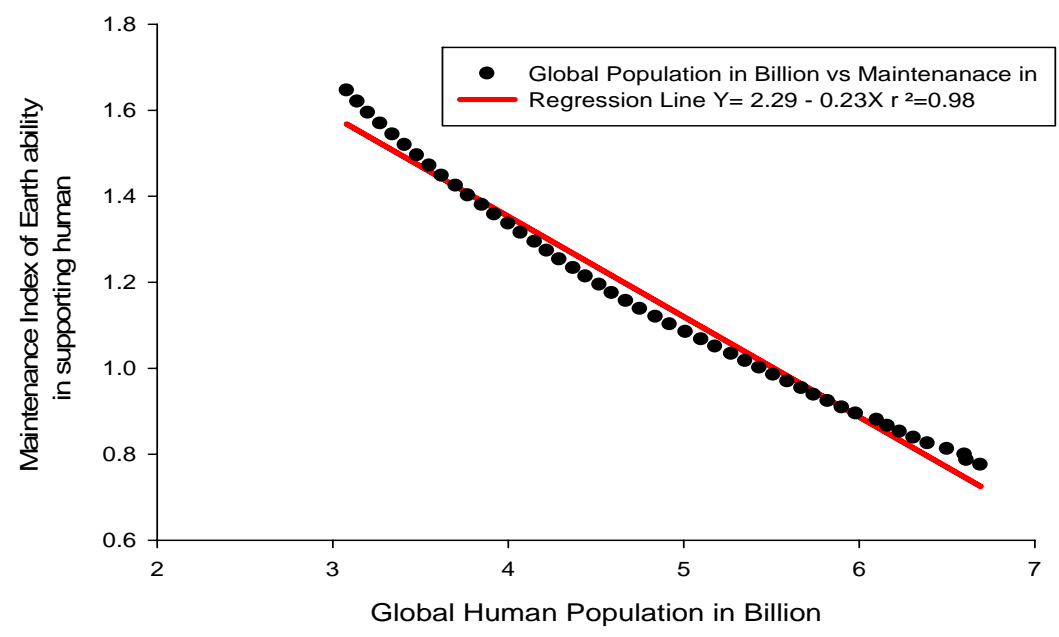

Fig. (6) Relatiosnhip between human population in billion and the maintenace index of the Earth using advanced technologies and information Theory

Figure (6) shows that there is a decline in the maintenance index that explains the Earth disability to maintain its ability to support all the human living on this Earth by supporting and providing the required natural resources to produce the goods and services that all the humans which are in need. 


\section{4) Modeling the Ecological Human Imprint and Impacts}

Figure (7) shows the human population at growth rate $1 \%$, global biological capacity and global biological demands from the Earth as calculated by the $\mathrm{E}_{\mathrm{HI}}$ index using information theory that includes the human technological advances. The graph shows the closing the gap between the total demands and total production and services with the global increase of the human population in spite of the very little increase in the demands than the biological capacities. The method has made close gaps between human population growth, demands and production of capacities and services that are needed from the natural resources. In this respect, because we take into consideration the technological advances in creation of biological goods and services to meet the demands and needs, this index has added a new dimension to reduce the gaps for production and demands. However, with increasing the human population in the current trends of growth ratewill be still a concern (UNDP, 2013). Currently, UNDP in 2015 developed several goals which are: 1) eradicate extreme poverty and hunger; 2) achieve universal primary education; 3) promote gender equality and empower women; 4) reduce child mortality; 5) improve maternal health; 6) combat HIV/ AIDS; 7) ensure environmental sustainability; and 8) develop a global partnership for development. These goals should be accompanied, in my opinion, by achieving the goals of reduction of human population growth rate. This will add a new dimension by reduction of use the natural resources to allow the global building of biological capacities of natural resources. These natural resources need time factor to increase and build up its capacities and renewing its capacities.

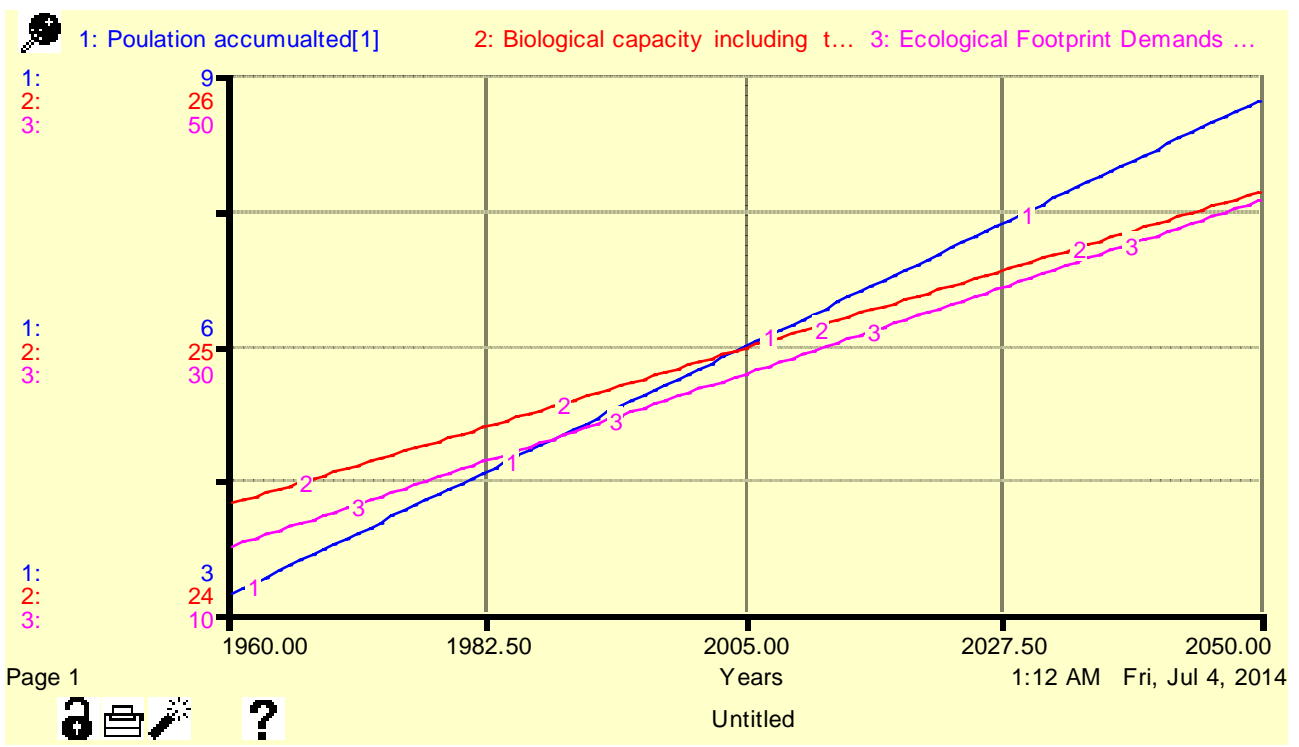

Figure (7) Relationship between increasing buman population (at growth rate at $1 \%$ as

a moderate assumption) and global biological capacities and global demands as calculated by $E_{H I}$ index using information theory and including the advanced technologies 
1: Poulation accumualted[1]

2: Biological capacity including t... 3: Ecological Footprint Demands ...

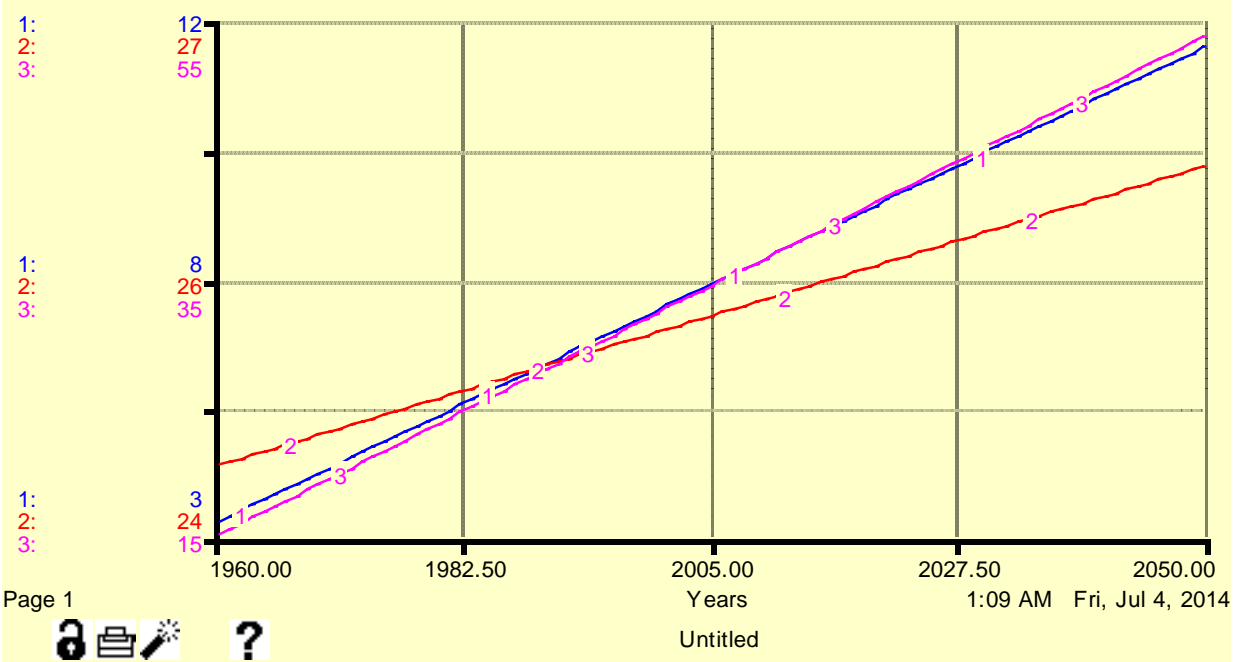

Figure (8) Relationship between increasing human population (at growth rate at 2\%

as relaxed assumption and global biological capacities and global demands as calculated by $E_{H I}$ index using information theory and including the advanced technologies

Figure (8) shows the human population at growth rate $2 \%$, global biological capacity and global biological demands from the Earth as calculated by the $E_{H I}$ index using information theory that includes the human technological advances. The graph shows that the gap between human population data has increased and widen so much rather than the Earth biological capacity in spite of increasing the technological advances of human. Figure (9) indicates that the increasing

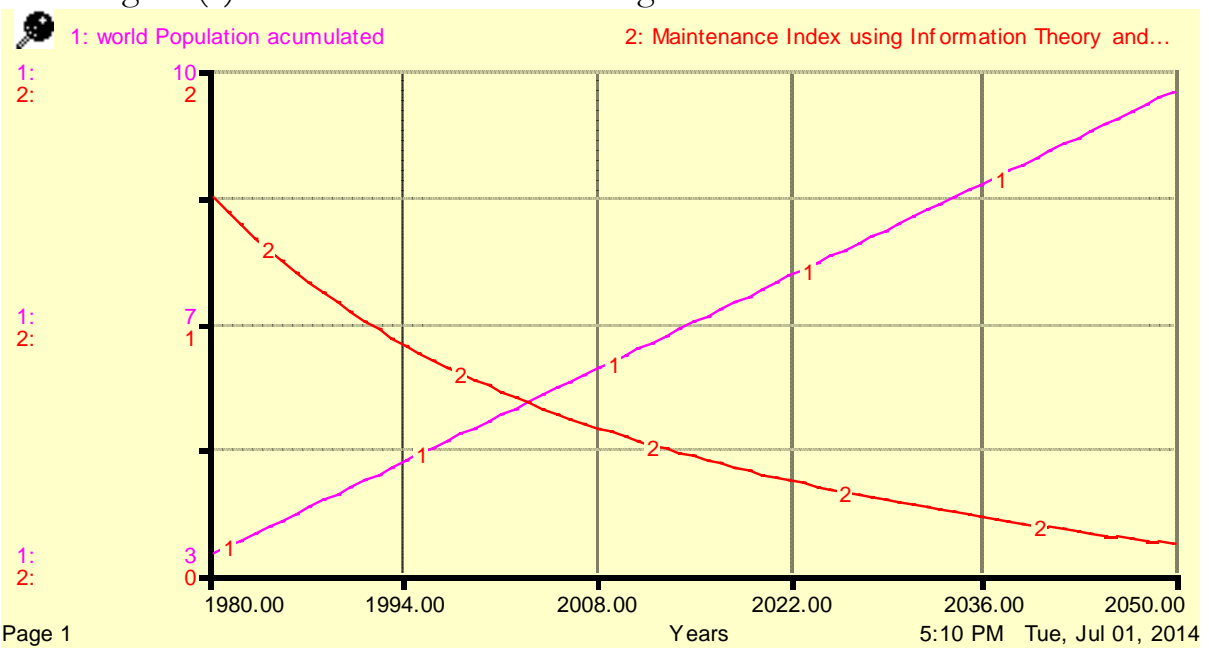

\section{昌米?}

Figure (9) Relationship between increasing human population (at growth rate at 2.0\%

as relaxed assumption) and global maintenance calculated by using $E_{H I}$ index using

information theory and including the advanced technologies 


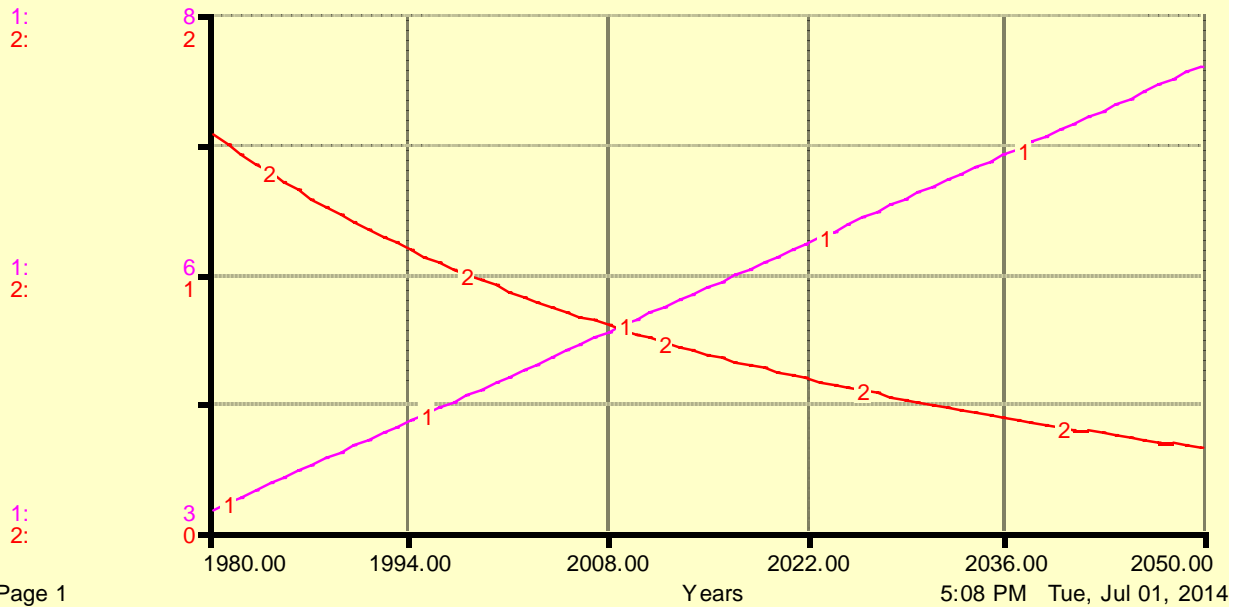

Page 1

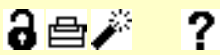

Figure (10) Relationship between increasing human population (at growth rate at 1.0\%

as moderate assumption) and global maintenance calculated by using $E_{H I}$ index using information theory and including the advanced technologies

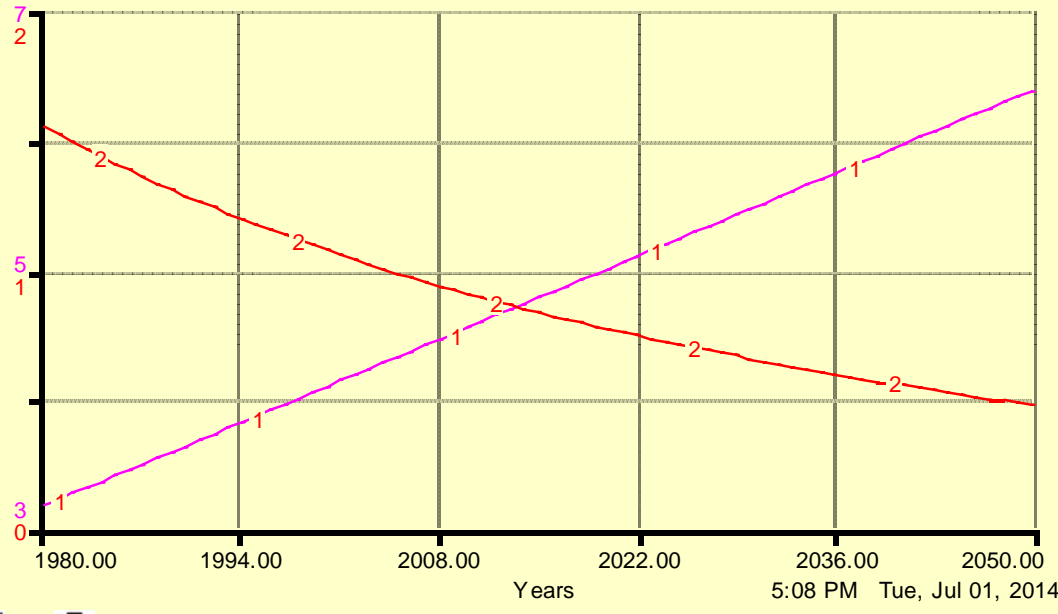

Page 1

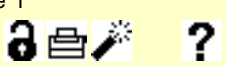

Figure (11) Relationship between increasing human population (at growth rate at $0.5 \%$ as conservative assumption) and global maintenance calculated by using $E_{H I}$ index

using information theory and including the advanced technologies human populations and global maintenance as calculated by using $\mathrm{E}_{\mathrm{HI}}$ index using information theory and using advanced technologies, there is a breakeven point between the human population and maintenance index at year 1996 and year 2015 when the population growth rate 
between $0.5 \%$-2.0(i.e. between very conservative assumption and relaxed assumption of prediction of human population growth).

\section{Discussion}

Sustainable development is an important concern because the global population humanity has increased in an alarming rate against the availability of natural resources that support their existence to get the goods and services, they are in need. It is important to our global humanities to understand that the global economy success is depending on the availability of natural resources (i.e. renewable and non-renewable) that is supporting our humanity with goods and services that we are using on a daily basis (Shakir Hanna and Osborne-Lee, 2011, 2012 and Shakir Hanna et. al, 2013). $\mathrm{E}_{\mathrm{HI}}$ is an index to support the issue of the regenerative capacity of Earth to support the human beings and to be balanced with the demands. The index is considering the positive and negative impacts of human on the environment using the advanced technologies and using the information theory for the calculation of the biological capacity of and the demands from the Earth. In this respect sustainability is to allow extending the life of the natural resources to be used several times. This will provide and cover the need of all human living on this Earth. In the most-recent assessment (Wackernagel and Galli, 2012) showed that the Earth is supporting 1.8 global hectare per capita. However, the demand from Earth is equal to 2.7 global hectare per/ capita. Therefore; the demands by humans from the nature have exceeded the capacity of the production of the nature. This indicates that the demand by human from nature is exceeding the Erath supporting the human by $150 \%$ than the Earth can provide. On the other hand, in figures (7-11) when our model of $\mathrm{E}_{\mathrm{HI}}$ included in the calculation the human technological advances either positively or negatively, there is an increase in the breakeven point between the growth human population and the maintenance index of Earth supporting all humans. This has been indicated that at $0.5 \%$ population growth rate, the Earth has maintained its ability to support all humans to year 2015-2017, and in the opposite when the human growth rate increased to $1 \%$ the Earth has maintained its ability to support all humans to year 2008. This added more extra years from the original breakeven point of year 1981 (Wackernagel et. al.; 2002, Shakir Hanna and Osborne-Lee, 2011, 2012, and Shakir Hanna et.al. 2013) as predicted by the $\mathrm{E}_{\mathrm{HI}}$ model. Therefore, from the above discussion, we can conclude that the Earth will not be able to support the more human beings that are added to the globe (Shakir Hanna and Osborne-lee, 2011, 2012, Shakir Hanna et. al., 2013a, b, and Steffenet.al, 2007). This is an alarming for the leaders of the world, communities, decision makers, governments, non-government organization (NGO), United Nation (UN), to look seriously at the human population issue and the Earth sustainability. Additionally, the urgent efforts to control the human population growth in order to maintain our global universe health production and regenerative capacity, otherwise, the nature will take its course by creating disasters that will affect all the living human beings causing real death of the human populations to balance the nature well beings.

Another aspect of human imprints on global environment, global economics and sustainability is how to maintain sustainable development within the limitation of 
resources' availability, and the human growth rate are not balanced with the nature support. In this respect, Brown et. al., 1987 indicated that the human survival requires sufficient food, probable water, uncontaminated air, adequate shelter and clothing, energy, and minerals. These needs are closely tied to the continuously functioning of the supporting ecological systems which maintain nutrient, air, and water cycles, and so the maintenance of renewable biological resources such as forest, and fishers stock. Beyond the basic, biological survival needs, however, there are variations in social and cultural perspectives on what is needed for quality existence and in ecological perspectives on what is needed for sustainable biosphere. This is the key for sustainability, which maintain the sustainable development and coincide with maintain the healthy growth of human population. In this consideration, the integrated natural resources' management is a conscious process of incorporating the multiple aspects of natural resource use into a system of sustainable management to meet the goals of resource users, managers and other stakeholders (e.g. production, food security, profitability, risk aversion and sustainability goals). To fulfill its aims, an integrated natural resource management approach is necessarily adaptive, interdisciplinary and involves a diverse set of stakeholders (Sayer, J. and Campbell, B. 2004).

\section{Conclusion}

Ecological Human Imprint $\left(\mathrm{E}_{\mathrm{HI}}\right)$ is an index to support the utilization of the Ecological Footprint. However, the method has added another dimension, which is the human technological advances, including the positive and negative impacts of human, in addition to use the information theory for the calculation. The index simulation model has shown that with the decreasing human population growth rate from the rates between $2 \%$ to $0.5 \%$ has increased the time for using of natural resources from year 1981 to year 2017 and to be at the breakeven point of balancing with nature. Therefore, without the value added of human advanced technologies and information theory, the breakeven point of use of the nature has shown a better understanding of the use of the nature. It is very important to educate all human beings for the danger of increasing human population without real balance with the natural ecosystem biological capacities of Earth to meet all humans the needs for goods and services from the Earth.

\section{References}

Abson, D.J., vonWehrden. H.,Baumgärtner, S., Fischer, J., Hanspach, J, Härdtle, W., Heinrichs, H, Klein, A.M., Lang, D.J., Martens P., and Walmsley, D. (2014). Ecosystem services as a boundary object for sustainability. Ecological Economics. 103: 29-37.

Andreopoulou, Z. S. (2012). Green Informatics. ICT for Green and Sustainability. Journal of Agricultural Informatics. Vol. 3, No2.

Andreopoulou, Z.S., B. Manos, N. Polman and D. Viaggi. (2011). Agricultural and Environmental Informatics, Governance, and Management: Emerging Research Applications. IGIGlobal. USA.

Andreopoulou, Z., Samathrakis, V., Louca, S., \& Vlachopoulou, M. (2014). E-Innovation for Sustainable Development of Rural Resources During Global Economic Crisis (pp. 1-317). Hershey, PA: IGI Global. doi:10.4018/978-1-4666-4550-9

Brown,J.B., Hanson, M.E., Liverman, D.M. and Merideth, R.W. (1987). Term Global Sustainability: Toward definition. Environ. Management Vol 11(6) 713-719. 
FAO (1960-2008). FAOSTAT FAO Statistical Database- Data Series 1960-2008. Food and Agriculture Organization, UN, www.fao.org, Rome, Italy.

FAO (2008).FAOSTAT Data Series. Food and Agriculture Organization, UN, www.fao.org, Rome, Italy.

Helsinki, (1993) Second Ministerial Conference on the Protection of Forests in Europe. 16-17 June 1993, Helsinki / Finland RESOLUTION H1 General Guidelines for the Sustainable Management of Forests in Europe. 5 pp.

Lee, S.M. (1991) Sustainable Development: A critical review. World Development, Vol. 19:607-621.

MA, (2005).Ecosystems and Human Well-being: Current State and Trends. Island Press, Washington, DC.

NOAA (2012).http://www.noaa.gov/climate.html.

Pearce, D. (1994). Sustainable consumption through economic instruments. Paper prepared for the Government of Norway Symposium on Sustainable Consumption, Oslo,19-20 January, 1994.

Rees, W.E. (2013) Ecological Footprint, Concept of. Encyclopedia of Biodiversity (Second Edition): 701 713.

Rees, W.E. (2010), "The Human Nature of Unsustainability", in Heinberg, Richard and Leich,Daniel,The Post Carbon Reader: Managing the 21st Century Sustainability Crisis, Watershed Media, ISBN 978-0-97095006-2.

Rees W.E. (2006). Ecological footprints and bio-capacity: essential elements in sustainability assessment. In: J. Dewulf and H.V. Langenhove (Editor), Renewables-Based Technology: Sustainability Assessment. John Wiley and Sons, Chichester, pp. 143-158.

Rees W.E. (2003). Economic development and environmental protection: an ecological economics perspective. Environmental Monitoring and Assessment, 86:29-45.

Rees, W.E. (2001) Ecological footprint, concept of. Encyclopedia of Biodiversity, Volume 2.Academic Press.229-244.

Rees, W.E. (2000). Eco-footprint analysis: merits and brickbats. Ecological Economics 32:371-374.

Rees, W. (1994).Sustainability, growth, and employment: Toward an ecologically stable, economically secure, and socially satisfying future. Paper prepared for the IISD Employment and Sustainable Development Project. Winnipeg, Manitoba: International Institute for Sustainable Development. (Revised version in Alternatives21:4 [October/November 1995]).

Rees, W.E. (1992a). Understanding sustainable development: Natural capital and the new world order. UBCSchool of Community and Regional Planning, Vancouver, Canada.

Rees, W.E. (1992b). Ecological footprints and appropriated carrying capacity: what urban economics leaves out? Environment and Urbanisation 4 (2): 121-130.

Rees, W.E. (1988). Cumulative environmental assessment and global change. Environmental Impact Assess.

Rees, W.E., and Wackernagel, M. (1996 a). Urban ecological footprints: why cities cannot be sustainable-and why they are a key to sustainability. Environmental Impact Assessment 16, 223e248.

Rees, W.E., and Wackernagel, M. (1996 b) Ecological Footprints and Appropriated Carrying Capacity: Measuring the Natural Capital Requirements of the Human Economy. Focus, v6 n1 p45-60.

Rees, W.E., and Wackernagel, M. (1994) Ecological footprints and appropriated carrying capacity: measuring the natural capital requirements of the human economy," In A. Jansson et al., Investing in Natural Capital: The Ecological Economics Approach to Sustainability, Washington, D.C., Island Press.

SAS (2010) SAS Statistical Package Version 9.2 for PC. Base SAS 9.2 Procedures Guide: Statistical Procedure, Third Edition.

Sayer, J. and Campbell, B. 2004. The Science of Sustainable Development: Local Livelihood and the Global Environment. Cambridge University Press. 263 pp. +xvii

Shakir-Hanna, S.H. and Osborne-Lee I.W. (2011). Sustainable economy of the ecological footprint: Economic analysis and impacts. In: Y. Villacampa and C.A. Brebbia (Editor), Ecosystems and Sustainable Development. VIII. WIT Press, South Hampton, UK, pp. 313-326.

Shakir- Hanna, S.H. and Osborne-Lee I.W. (2012). Modeling and Evaluating the Global Energy Flow in Ecosystems and its Impacts on the Ecological Footprint. In: Jordán, F., Jørgensen, S.E. (Eds), Models of the Ecological Hierarchy: From Molecules to the Ecosphere. Elsevier B.V., pp. 469498.

Shakir- Hanna, S.H., Osborne-Lee I.W. and Khakil, M.T. (2013 a). Sustainable Economy of Ecological Footprint in Africa: An Economic Analysis and Impacts. World Environment 2013, 3(1): 9-17. 
Shakir Hanna, S.H., Harris, K.T., Osborne-Lee, I.W., Gian Paolo, C., Misso, R. and Khalil, M.T. (2013b) (in press Accepted). Global Ecological Footprint, Climate Change Impacts and Assessment, 23 pages RIVISTA DI STUDI SULLA SOSTENIBILITA Review of Studies on Sustainability.

Shannon, C.E. and Weaver, W. (1949). The Mathematical Theory of Information. 125 pp. Urbana, Univ. of Illinois Press.

SPSSSCIENC (2002).Sigmaplot Version 8. SPSSSCIENCE www.spssscience. Com / sigmaplot.

SPSSSCIENC (2009-2010).SigmaPlot 11.2. User's Guide Part 1.by System Software. 890 + index 50 pp.

SPSSSCIENC (2009-2010).SigmaPlot 11.2.User's Guide Part 2 Statistics .by System Software.564 pp.

STELLA (2001).An Introduction to System Thinking by Barry Richmond. High Performance Systems, Inc. High Performance Systems, Inc. The System Thinking Company.ISBN 0-9704921-1-1, 165 PP.

Steffen, W., Crutzen, P.J, and McNeill, J.R (2007) The Anthropocene: Are Humans Now Overwhelming the Great Forces of Nature? Ambio 36 (8) 614-621- Royal Swedish Academy of Science.

UNDP (2013). The Rise of the South: Human Progress in a Diverse World. Human Development Report 2013.the United Nations Development Programme. Gilmore Printing Services Inc., Canada 216 pp.

UNEP (2009). A Planet in Ecological Debt, Arendal Maps and Graphics Library: UNEP

http://maps.grida.no/go/graphic/a-planet-in-ecological-debt.

UNFPA (2001).The State of World Population 2001.

USDHHS and USDA (2005).Dietary Guidelines for Americans. U.S. Department of Health and Human Services and U.S. Department of Agriculture, $71+$ IV PP + Appendix p.

USDA (2012) http://ers.usda.gov/data-products.aspx\#.UnuTTTbrnbIV

Von Weizsacker, E. U.and Ernst U. (1994). Earth Politics. London: Zed Books.

Venetoulis, J. andTalberth, J (2010) Refining the Ecological Footprint. In: OkechukwuUkaga, Chris Maser andMichael Reichenbach (eds.) Sustainable Development: Principles, Frameworks, and Case Studies (Social Environmental Sustainability) Pages 57-94. Taylor and Francis Group, LLC.

Wackernagel, M., 1991. "Land Use: Measuring a Community's Appropriated Carrying Capacity as an Indicator for Sustainability"; and "Using Appropriated Carrying Capacity as an Indicator, Measuring the Sustainability of a Community." Report I \& II to the UBC Task Force on Healthy and Sustainable Communities, Vancouver.

Wackernagel, M., 1994. Ecological Footprint and Appropriated Carrying Capacity: A Tool for Planning Toward Sustainability. Ph.D. Thesis. School of Community and Regional Planning. The University of British Columbia.

Wackernagel, M., and Rees, W. E., (1991).

Wackernagel, M., and Rees, W. E., (1996). Our Ecological Footprint: Reducing Human Impact on the Earth. New Society Publishers, Gabriola Island, British Columbia, Canada.German edition with updated data, 1997.Birkha" user, Basel, 1997.

Wackernagel, M. and Galli, A. (2012) Ecological footprint: Economic Performance and resource constrains. Global Dialogue, 14, (1) Winter/Spring 2012 Networking Sustainability.

Wackernagel, M., Schulz, N. B., Deumling, D, Linares, A.C., Jenkins, M, Kapos, V., Monfreda,C., Loh,J., Myers,M.,Norgaard, R., and Randers, Jørgen (2002) Tracking the ecological overshoot of the human economy. PNAS.Vol. 99, 9266-9271.www. pnas. org_cgi_doi_10.1073_pnas. 142033699

WHO (2005) Ecosystems and human well-being: health synthesis: A report of the Millennium Ecosystem Assessment. 53pp. Printed in France.

WorldBank, 1960-2012. Data Series and Research.The World Bank organization.http://data.worldbank.org/topic/ agriculture-and-rural-development.

WorldBank,1960-2008. Data Series and Research.The World Bank worldbank.org/topic/ agriculture-andrural-development.

WRI, 1960-2005 Series. EarthTrends Environmental Information, World Resource Institute (WRI). World Resource Institute:WRIhttp://Earthtrends.wri.org/.

WRI(2000). World Resources 2000-2001-People and Ecosystems: The Fraying Web of Life. World Resources Institute (WRI), Washington DC, USA.

WRI (2012) U.S. Drought Demonstrates Complexity, Severity of Water Risk by RobertKimball.http://www.wri.org/search/site/Robert $\% 2520$ Kimball $\% 2520$ and $\% 2520$ drought.

WWF (2002) The Global Conservation Organization, living planet report/ footprint.

WWF (2002) Living Planet Report 2002, World Wide Fund for Nature

(WWF),http://www.panda.org/livingplanet., Geneva, Switzerland. 
WWF (2002) Living Planet Report 2002 Edited by Jenkins M., Jakubowska J., Gaillard V., Groombridge B., M.WackernagelMonfreda, C., Deumling D., Gurarie E., Friedman S., Linares A.C., Sánchez M.A.V., Falfán I.S.L., Loh, J. Randers., S.J. and C.Monfreda, World Wildlife Fund (WWF), www.panda.org, International. Avenue du Mont-Blanc, CH-1196 Gland, Switzerland

WWF (2004).Living Planet Report 2004, World-Wide Fund for Nature International (WWF), Global Footprint Network, UNEP World Conservation Monitoring Centre.WWF, Gland, Switzerland.http://www.panda.org/livingplanet.

WWF (2006). Living Planet Report 2006, World Wide Fund (WWF) for Nature,

Gland,Switzerlandhttp://www.panda.org/livingplanet.

WWF (2008).Living Planet Report 2008. Edited by Humphrey S., Chapagain A., Bourne G., Mott R., Oglethorpe J., Gonzales A., Atkin M., Loh J., Collen B., McRae L., Carranza T.T., Pamplin F.A., Amin R., Baillie J.E.M., Goldfinger S., Wackernagel M., Stechbart M., Rizk S., Reed A., Kitzes J., Peller A., Niazi S., Ewing B., Galli A., Wada Y., Moran D., Williams R., Backer W.D., Hoekstra A.Y. and Mekonnen, M., World Wide Fund (WWF), www.panda.org, International Avenue du Mont-Blanc 1196 Gland, Switzerland.

WWF, 2010.Living Planet Report.World Wide Fund for Nature, Gland, Switzerland.Yale Center for Environmental Law \& Policy/Center for International Earth Science Information Network at Columbia University, 2010. 2010 Environmental Performance Index, http://epi.yale.edu/Home (accessed September 2010).

WWF (2012) Living Planet Report 2012.Biodiversity, biocapacity and better choices.Editor in chief: Monique Grooten., Lead editors: Rosamunde Almond and Richard McLellan. Editorial team: Nigel Dudley, Emma Duncan, NatasjaOerlemans and Sue Stolton.

\section{Appendix A}

Table (1) list of variables and parameters that are used in the $E_{H I}$ of Global Ecological Footprint

\begin{tabular}{|c|c|c|}
\hline Variables & Interpretation & Unit used in the model \\
\hline $\mathrm{H}_{\mathrm{p}}$ & World Population Series & In Billion individuals \\
\hline $\mathrm{E}_{\mathrm{F}}$ & Total Ecological Foot Print & In billion global hectares \\
\hline $\mathrm{G}_{\mathrm{BC}}$ & $\begin{array}{l}\text { Global Biological Capacity of the } \\
\text { Earth }\end{array}$ & $\begin{array}{l}\text { In billion global hectares that generate the } \\
\text { biological capacity of the Earth }\end{array}$ \\
\hline $\mathrm{G}_{\mathrm{BD}}$ & $\begin{array}{l}\text { Global Biological Demand from the } \\
\text { Earth }\end{array}$ & $\begin{array}{l}\text { In billion global hectares that consumed from } \\
\text { biological capacity by human beings from the } \\
\text { Earth }\end{array}$ \\
\hline $\mathrm{C}_{\mathrm{F}}$ & Cropland Footprint & In billion global hectares of cropped lands \\
\hline $\mathrm{G}_{\mathrm{LF}}$ & Grazing Land Footprint & In billion global hectares of grazed lands \\
\hline $\mathrm{F}_{\mathrm{GF}}$ & Forest Ground Footprint & $\begin{array}{l}\text { In billion global hectares of forest lands } \\
\text { excluding fuel wood }\end{array}$ \\
\hline $\mathrm{F}_{\mathrm{F}}$ & Fish Ground Footprint & In billion global hectares of fishing farming \\
\hline $\mathrm{B}_{\mathrm{L}}$ & Built-up Land & In billion global hectares \\
\hline $\mathrm{G}_{\mathrm{DC}}$ & Global Deficit Capacity & In billion hectares \\
\hline $\mathrm{G}_{\mathrm{EAgLI}}$ & $\begin{array}{l}\text { Global Efficiency of Agriculture } \\
\text { lands Index }\end{array}$ & As a Ratio \\
\hline $\mathrm{G}_{\mathrm{EALI}}$ & $\begin{array}{l}\text { Global Efficiency of Arable Lands } \\
\text { Index }\end{array}$ & As a ratio \\
\hline $\mathrm{E}_{\mathrm{HI}}$ & Ecological Human Imprint Index & $\begin{array}{l}\text { Calculated by Information Theories and } \\
\text { Technological Advances Factor as positive and } \\
\text { negative impacts and converted to Global billion } \\
\text { hectares }\end{array}$ \\
\hline
\end{tabular}

The model used parameters such as world human population series $\left(\mathrm{H}_{\mathrm{P}}\right)$ from year 1961 to 2009, Ecological Foot Prints, Maintenance Index (MI) as calculated by information 
theory. Further, other terms such as the $\mathrm{G}_{\mathrm{BC}}$ which is the Global Biological Capacity and $\mathrm{G}_{\mathrm{BD}}$ which is Global Biological Demand, Cropland Footprint $\left(\mathrm{C}_{\mathrm{F}}\right)$ in billion global hectares, Grazing Land Footprint $\left(\mathrm{G}_{\mathrm{LF}}\right)$ in billion global hectares, Forest Ground Footprint $\left(\mathrm{F}_{\mathrm{GF}}\right)$ excluding fuel wood in billion global hectares, fish ground footprint $\left(\mathrm{F}_{\mathrm{F}}\right)$ in billion global hectares, Built-up Land $\left(\mathrm{B}_{\mathrm{L}}\right)$ in billion global hectares, Global Deficit Capacity $\left(\mathrm{G}_{\mathrm{DC}}\right)$ in billion hectares, are used in calculations, $\mathrm{G}_{\text {EAgLI, }}$ is the Global Efficiency of Agriculture lands Index, GeALI Global Efficiency of Arable Lands Index and Ratio of Global Bio-capacity of the Earth to Global Agriculture Land $G_{B C} / G_{A L}$,

Table (2) Global Population, Global Biological Capacity ( $\mathrm{G}_{\mathrm{BC}}$ ), Global Biological Demand $\left(\mathrm{G}_{\mathrm{BD}}\right)$ and Maintenance Index of Our Planet Earth from Year 1961 to Year 2008 - Data are in 10 years intervals *

\begin{tabular}{|c|c|c|c|c|c|c|c|}
\hline Year & $\begin{array}{l}\text { Global } \\
\text { Population } \\
\text { in billion }\end{array}$ & $\begin{array}{l}\text { Total } \\
\text { Global } \\
\text { Biological } \\
\text { Demand } \\
\text { (GBD) } \\
\text { (billion } \\
\text { global ha) }\end{array}$ & $\begin{array}{l}\text { Total } \\
\text { Global } \\
\text { Biological } \\
\text { Capacity } \\
\text { (GBC) } \\
\text { (billion } \\
\text { global ha) }\end{array}$ & $\begin{array}{l}\text { Total } \\
\text { Global } \\
\text { Biological } \\
\text { Demand } \\
\text { as } \\
\text { calculated } \\
\text { by } E_{\mathrm{HI}} \\
\text { (n billion } \\
\text { global ha) }\end{array}$ & $\begin{array}{l}\text { Total } \\
\text { Global } \\
\text { Biological } \\
\text { Capacity } \\
\text { as } \\
\text { calculated } \\
\text { by E }{ }_{H I} \\
\text { (billion } \\
\text { global ha) }\end{array}$ & $\begin{array}{l}\text { Maintenance } \\
\text { index } \\
\text { without } \\
\text { using } \mathrm{E}_{\mathrm{HI}}\end{array}$ & $\begin{array}{l}\text { Maintenance } \\
\text { index using } \\
\mathrm{E}_{\mathrm{HI}}\end{array}$ \\
\hline 961 & 3.08 & 7.47 & 10.90 & 14.80 & 24.40 & 1.45 & 1.65 \\
\hline 970 & 3.70 & 9.50 & 11.00 & 17.66 & 24.53 & 1.15 & 1.38 \\
\hline 980 & 4.44 & 11.25 & 11.13 & 20.53 & 24.66 & 0,98 & 1.20 \\
\hline 990 & 5.27 & 12.93 & 11.38 & 23.40 & 24.79 & 0.88 & 1.05 \\
\hline 000 & 6.10 & 15.1 & 12.00 & 26.27 & 24.92 & 0.79 & 0.94 \\
\hline 008 & 6.69 & 18.8 & 12.00 & 28.56 & 25.02 & 0.66 & 0.87 \\
\hline
\end{tabular}

* Data Sources are World Bank-FAO - WWF - Ecological Footprint Network - WRI-Earth Trends US Estimates, 
Table (3) Predicted Values Calculated for Global Population, Global Biological Capacity $\left(\mathrm{G}_{\mathrm{BC}}\right)$, Global Biological Demand $\left(\mathrm{G}_{\mathrm{BD}}\right)$ and Maintenance Index of Our Planet Earth from Year 2009 to Year 2050. The Presented Data are in 10 Years intervals on the bases of current trend of estimate of population growth rate and other parameters

\begin{tabular}{|c|c|c|c|c|c|c|c|}
\hline Year & $\begin{array}{l}\text { Global } \\
\text { Population } \\
\text { in billion }\end{array}$ & $\begin{array}{l}\text { Total } \\
\text { Global } \\
\text { Biological } \\
\text { Demand } \\
\text { (GBD) } \\
\text { (billion } \\
\text { global ha) }\end{array}$ & $\begin{array}{l}\text { Total } \\
\text { Global } \\
\text { Biological } \\
\text { Capacity } \\
\left.\text { (G }{ }_{\mathrm{BC}}\right) \\
\text { (billion } \\
\text { global ha }\end{array}$ & $\begin{array}{l}\text { Total } \\
\text { Global } \\
\text { Biological } \\
\text { Demand } \\
\text { as } \\
\text { calculated } \\
\text { by E EI } \\
\text { (n billion } \\
\text { global ha) }\end{array}$ & $\begin{array}{l}\text { Total } \\
\text { Global } \\
\text { Biological } \\
\text { Capacity } \\
\text { as } \\
\text { calculated } \\
\text { by E EI } \\
\text { (billion } \\
\text { global ha }\end{array}$ & $\begin{array}{l}\text { Maintenance } \\
\text { index } \\
\text { without } \\
\text { using } \mathrm{E}_{\mathrm{HI}}\end{array}$ & $\begin{array}{l}\text { Maintenance } \\
\text { index using } \\
\mathrm{E}_{\mathrm{HI}}\end{array}$ \\
\hline 009 & 6.74 & 16.98 & 11.94 & 29.58 & 25.07 & 0.70 & 0.84 \\
\hline 010 & 6.79 & 17.11 & 11.95 & 29.88 & 25.08 & 0.69 & 0.84 \\
\hline 020 & 8.83 & 22.46 & 12.13 & 32.89 & 25.21 & 0.54 & 0.76 \\
\hline 030 & 9.17 & 28.62 & 12.31 & 36.90 & 25.35 & 0.43 & 0.68 \\
\hline 040 & 9.51 & 31.30 & 12.52 & 38.91 & 25.48 & 0.40 & 0.65 \\
\hline 050 & 9.84 & 33.36 & 12.73 & 41.92 & 25.62 & 0.38 & 0.61 \\
\hline
\end{tabular}

